\title{
APLIKASI KELAYAKAN KUALITAS AIR ASPEK MIKROBIOLOGI PADA SISTEM RESIRKULASI UNTUK MENDUKUNG PERTUMBUHAN BENIH IKAN KAKAP PUTIH (Lates calcarifer Bloch)
}

\section{WATER QUALITY FEASIBILITY APPLICATIONS OF MICROBIOLOGY ASPECT IN RESIRCULATION SYSTEM TO SUPPORT GROWTH OF SEABASS SEEDS (Lates calcarifer Bloch)}

\author{
Rahmi $^{1^{*}}$ dan Ramses ${ }^{2}$ \\ ${ }^{12}$ Program Studi Pendidikan Biologi, Fakultas Keguruan dan Ilmu Pendidikan \\ Universitas Riau Kepulauan. Batam- Indonesia \\ *Koresponden: rahmikumbang@gamail.com
}

\begin{abstract}
Abstrak
Pengelolaan benih Kakap Putih menggunakan sistem resirkulasi di dalam ruangan (indoor) dilakukan untuk mengatasi permasalahan-permasalahan yang timbul karena pengaruh iklim dan kerusakan lingkungan. Penelitian ini dilaksanakan pada tanggal 24 April - 22 Juni 2016 yang bertempat di Balai Perikanan Budidaya Laut (BPBL) Batam, Propinsi Kepulauan Riau. Penelitian dilakukan dengan memelihara benih Kakap Putih pada bak $10 \mathrm{~m}^{3}$, ukuran benih berkisar $3-4 \mathrm{~cm}$ dengan berat berkisar 0,75 gr. Ikan Kakap Putih dipelihara selama dua bulan. Pengecekan mikrobiologi dilakukan dua minggu sekali. Pengukuran pertumbuhan dilakukan satu minggu sekali dan penghitungan tingkat kelulusan hidup dilakukan diakhir masa pemeliharaan. Selain pengambilan data diatas, juga melakukan pengukuran terhadap parameter kualitas air seerti salinitas, DO, tempratur dan $\mathrm{pH}$. Hasil pengamatan menunjukkan bahwa jumlah bakteri umum (TBU) pada media air sistem resirkulasi berkisar antara $4,12 \times 10^{4}$ sampai $9 \times 10^{4} \mathrm{CFU} / \mathrm{ml}$. Sedangkan jumlah bakteri vibrio (TBV) berkisar antara $1,3 \times 10^{3}$ sampai $5,2 \times 10^{3} \mathrm{CFU} / \mathrm{ml}$. Hasil ini tidak berbeda jauh dengan pemeliharaan tanpa resirkulasi. Namun pada pengecekan kualitas air terhadap $\mathrm{pH}$, DO, salinitas dan suhu pada sitem resirkulasi dapat mempertahan kualitas air yang optimal sehingga pertumbuhan dan angka kelulusan hidup benih Kakap Putih termasuk baik.
\end{abstract}

Kata kunci : Sistem resirkulasi, kualitas air, mikrobiologi, benih kakap putih, bakteri

\begin{abstract}
Seabass seeds growth management using indoor recirculation system was done to overcome arising problems due to climate influence and environmental damage. This research was conducted on April 24 to June 22, 2016 which was held at Marine Aquaculture Institute (Balai Perikanan Budidaya Laut; BPBL) Batam, Kepulauan Riau Province. The study was conducted by preserving the Seabass seeds on a $10 \mathrm{~m} 3 \mathrm{tub}$, seed size ranging from 3 to $4 \mathrm{~cm}$ with ranging from $0.75 \mathrm{gr}$ in weight. Seabass was kept for two months. Microbiological checking was done every two weeks. Growth Measurement was done once a week and living rate was done at the end of the preserving period. Beside the data collection
\end{abstract}


above, water quality feasibility measurements was also done such as salinity, DO, temperature and $\mathrm{pH}$. Observation results showed that common bacteria (TBU) amount in recirculation water system media was in ranging 4.12x104 to 9x104 CFU / ml. While vibrio bacteria (TBV) amount was in ranging $1.3 \times 103$ to $5.2 \times 103 \mathrm{CFU} / \mathrm{ml}$. These results was close to preserving wit no recirculation. However, on water quality checking of $\mathrm{pH}, \mathrm{DO}$, salinity and temperature in the recirculation system can optimalize water quality maintain, so that the Seabass seeds growth and living rate was categorized good.

Keywords: Recirculation System, Water Quality, Microbiology, Seabass Seeds, Bacteria

\section{PENDAHULUAN}

Pada sistem budidaya ikan kakap putih (Lates calcarifer), munculnya wabah penyakit menjadi salah satu ancaman utama terhadap keberlanjutan produksi (Novriadi, et all. 2014). Aspek mikrobiologi menjadi bagian terpenting dari kualitas air yang menentukan budidaya kakap putih. Bakteri adalah mikroorganisme yang dapat memiliki arti penting bagi perairan budidaya laut maupun perairan budidaya air tawar. Bakteri dapat menyebabkan penyakit yang merugikan dan menjadi indicator pencemaran. Salah satu parameter penunjang keberhasilan budidaya air laut maupun budidya air tawar adalah kondisi bakteriologis di dalam perairan budidaya tersebut (Sutiknowati, 2014)

Peranan bakteri yang sangat vital pada ekosisitem perairan laut adalah sebagai decomposer dengan hasil dekomposisi unsur-unsur mineral yang esensial sebagai sumber nutrient pada rantai makanan. Mikroorganisme tidak dapat dipisahkan dengan lingkungan abiotik dan biotik dari suatu ekosisitem karena peranannya sebagai pengurai. Salah satunya adalah peran mikroorganisme yang hidup pada lingkungan akuatik. Air alami tersedia sebagai habitat untuk sejumlah mikroorganisme. Berkitan dengan hal tersebut, kemunduran mutu air dapat mengakibatkan kematian, hambatan pertumbuhan, timbulnya hama/penyakit, pengurangan rasio konversi pakan, serta menurunnya mutu daging ikan (Hirayama 1974, Boyd, 1979 dalam Mayunar, 1991).

Perairan BPBL Batam di Pulau Setokok telah lama dimanfaatkan sebagai lokasi budidaya sejak 2002. Perubahan lingkungan akibat proses pembangunan diwilayah daratan sekitarnya menyebabkan degradasi lingkungan. Program pengecekan rutin kondisi kualitas air di BPBL Batam sangat diperlukan untuk mengetahui kelayakan media untuk sarana budidaya. Untuk itulah maka diperlukan pengecekan kondisi mikrobiologi air untuk sarana budidaya. Pada saat sekarang pengelolaan benih kakap putih menggunakan sistem resirkulasi di dalam ruangan (indoor), hal ini dilakukan untuk mengatasi permasalahan-permasalahan yang terjadi 
sebelumnya seperti diatas. Dengan sistem resirkulasi, kualitas air pada kegiatan pembenihan kakap menjadi lebih baik karena secara tidak langsung pengaruh musim dan curah hujan berkurang sehingga kualitas air tetap terjaga dengan baik dan hal ini dapat mengurangi persentase serangan penyakit terhadap benih kakap putih.

Keuntungan penggunaan system resirkulasi air pada pembenihan ikan lauta dalah peningkatan biosecurity dari potensi kontaminasi sumber air terbuka, kualitas air yang lebih stabil dan tidak terpengaruh dengan kondisi perairan, meningkatkan produksi sampai dengan $30 \%$, mengurangi ongkos produksi karena produktifitas yang meningkat, mengurangi kematian akibat lingkungan dan penyakit serta system pergantian air yang sangat kecil. Akhirnya limbah produksi pada system resirkulasi (partikel dan larutan) dapat dikontrol dan diminimalkan, sehingga menjadikan system ini ramah lingkungan.

Sistem resirkulasi atau Recirculating Aquaculture Systems (RAS) adalah system dengan penggunaan air buangan dengan perlakuan secara mekanik dan biologi.Sistem resirkulasi minimal efektif meliputi 1) aerasi, 2) pembuangan bahan partikel, 3) filter biologi untuk mereduksi sampah ammonia dan nitrit dan 4) buffer $\mathrm{pH}$.

Banyak faktor yang mempengaruhi keberhasilan kegiatan pembenihan ikan kakap putih, diantaranya adalah manajemen pemeliharaan. Pengelolaan air pada teknik pemeliharaan larva ikan kakap putih yang lama atau konvensional adalah dengan pergantian air laut langsung dari tandon yang setiap hari diganti pada saat penyiphonan mulai dilakukan (flowthrough). Pengelolaan air seperti ini mempunyai efek yang kurang baik, terutama pada saat musim hujan yang menyebabkan perubahan dan fluktuatif pada kualitas air (suhu, salinitas, $\mathrm{pH}, \mathrm{DO}$, turbidity, kandungan bakteri, dan lain-lain).

Filterisasi dan pengendapan, serta penggunaannya (air laut dengan proses sterilisasi yang dipergunakan banyak/tidak hemat) pun menjadi tidak optimal karena air mengendap tidak lama disebabkan kebutuhan akan air laut sebagai media pemeliharaan cukup banyak. Salah satu upaya dalam memperbaiki sistem manajemen pemeliharaan adalah melalui perbaikan pengelolaan dan pergantian air media pemeliharaan dengan sistem resirkulasi. Pemilihan pemeliharaan larva dengan sistem resirkulasi yang tepat dan sesuai dengan kebutuhan fisiologis dan biologis ikan yang dipelihara akan sangat mempengaruhi performa, tingkat pertumbuhan dan kelulushidupan larva ikan sehingga akan menghasilkan benih yang berkuantitas, berkualitas, dan berkontinyuitas, serta tahan terhadap serangan penyakit.

Khususnya aspek mikrobiologi, keberadaan bakteri dalam system resirkulasi terutama dalam air media pemeliharaan harus dikontrol dengan baik agar tidak tumbuh melebihi 
kemampuan atau daya tahan ikan sehingga dapat menyebabkan kematian. Oleh karena penting untuk mengetahui/mengamati parameter mikrobiologi khususnya fluktuasi nilai total bakteri umum (TBU) dan total bakteri Vibrio (TBV) dalam air media pemeliharaan benih ikan kakap putih.

Berdasarkan hal tersebut diatas, maka perlu dilakukan penelitian kelayakan kualitas air (mikrobiologi) pada sistem resirkulasi untuk mendukung pertumbuhan benih ikan kakap putih (Lates calcarifer, Bloch).

\section{METODOLOGI PENELITIAN}

\section{Waktu dan Tempat}

Kegiatan ini dilaksanakan pada tanggal 24 April - 22 Juni 2016 yang bertempat di Bagian Pembenihan Kakap Putih Balai Perikanan Budidaya Laut Batam,--Kepulauan Riau

\section{Alat dan Bahan}

Peralatan yang digunakanantara lain : Bak pemeliharaan larva/benih (beton) volume total $10 \mathrm{~m}^{3}$, Sistem resirkulasi (baktandon, sand filter, biofilter, pompa) selang dan batu aerasi, sifon, peralatan kerja (ember, gayung, dan lain-lain); peralatan sampling, peralatan pengecekan kualitas air, peralatan pengujian total bakteri umum dan total bakteri Vibrio (autoclave, hotplate stirrer, erlenmeyer, waterbath, laminar airflow, mikropipet, petridish, incubator, colony counter)

Bahan yang digunakan adalah: benih kakap putih, pellet komersial, bahan desinfektan; bahan sterilisasi, bahan pengujian Plate Count Agar (PCA), TCBS Agar, Sodium Chlorida, akuades.

\section{Metode Kerja}

Mekanisme/cara kerja yang digunakan pada penelitian ini adalah memelihara benih kakap putih pada bak $10 \mathrm{~m}^{3}$. Adapun ukuran benih kakap putih berkisar $3-4 \mathrm{~cm}$ dengan berat berkisar 0,75 gr. Ikan kakap putih dipelihara kurang lebih selama dua bulan. Media pemeliharaan dengan menggunakan sistem resirkulasi. Pengelolaan air dengan sistem resirkulasi adalah dengan cara membuang air bak sebanyak 10-20\% setiap hari setelah pemberian pakan. Instalasi air dibuat dengan system resirkulasi dimana air yang dipakai untuk pelihara benih akan berputar (resirkulasi) dengan melewati sand filter sehingga air tersebut dapat tersaring dengan baik. Agar air selalu tersedia dengan kualitas yang baik maka 
sand filter harus di backwash secara rutin sebanyak dua kali pada pagi dan sore hari. Pengambilan media pemeliharaan untuk pengecekan mokrobiologi dilakukan dua minggu sekali, sedangkan untuk pengecekan kualitas air rutin dilakukan seminggu sekali. Pengambilan sampel ikan untuk pengukuran pertumbuhan dilakukan satu minggu sekali dan penghitungan tingkat kelulusan hidup dilakukan diakhir masa pemeliharaan. Selain pengambilan data diatas, juga melakukan pengukuran terhadap parameter kualitas air yaitu $\mathrm{pH}, \mathrm{DO}$, salinitas dan suhu

Sampel air dilakukan pengujian untuk parameter angka lempeng total bakteri umum (TBU) dan total bakteri Vibrio (TBV) berdasarkan metode sesuai instruksi kerja di laboratorium. Adapun prosedur kerja pengujian adalah sebagai berikut :

1. Siapkan $9 \mathrm{ml}$ larutan trisalt yang telah disterilkan dalam tabung-tabung reaksi sesuai kebutuhan.

2. Buat seri pengenceran $0,10^{1}, 10^{2}, 10^{3}, 10^{4}, 10^{5}$, atau sesuai kebutuhan dengan bahan pengenceran trisalt steril, yaitu dengan cara mengambil $1 \mathrm{ml}$, dari larutan dengan pengenceran 0 dimasukkan kedalam $9 \mathrm{ml}$ larutan trisalt steril untuk mendapatkan pengenceran $10^{1}$

3. Kemudian $1 \mathrm{ml}$ dari pengenceran $10^{1}$ dimasukkan ke dalam $9 \mathrm{ml}$ larutan trisalt untuk mendapatkan tingkat pengenceran $10^{2}$, dan seterusnya.

4. Bakteri yang akan ditumbuhkan dalam media diambil dari tiga seri pengenceran yang sudah diperkirakan jumlah bakterinya sesuai dengan estimasi jumlah bakteri sampel

5. Pipet $1 \mathrm{ml}$ dari setiap pengenceran dan masukkan ke dalam cawan petri steril

6. Tambahkan/tuang Agar PCA (Plate Count Agar) yang sudah dikondisikan dalam water bath hingga suhu $45^{\circ} \mathrm{C} \pm 1^{\circ} \mathrm{C}$, sebanyak $12 \mathrm{ml}-15 \mathrm{ml}$ atau secukupnya kedalam masing-masing cawan petri yang sudah berisi sampel. Supaya sampel dan media PCA tercampur sempurna, lakukan pemutaran cawan ke depan dan ke belakang dan ke kiri ke kanan. Setiap seri pengenceran dikerjakan secara duplo

7. Setelah agar PCA menjadi padat, inkubasi cawan-cawan tersebut selama 24 jam \pm 2 jam pada suhu $28^{\circ} \mathrm{C}-30^{\circ} \mathrm{C}$ dengan posisi cawan terbalik.

8. Hitung jumlah koloni bakteri yang tumbuh pada cawan-cawan petri dengan colony counter 


\section{HASIL DAN PEMBAHASAN}

\section{Pengecekan TBU dan TBV}

Jumlah TBU dan TBV didapat bahwa kandungan bakteri umum pada media air system resirkulasi berkisar antara $4,12 \times 10^{4}$ sampai $9 \times 10^{4} \mathrm{CFU} / \mathrm{ml}$. Sedangkan jumlah bakteri vibrio berkisar antara $1,3 \times 10^{3}$ sampai $5,2 \times 10^{3} \mathrm{CFU} / \mathrm{ml}$. Jumlah bakteri diatas tidak mengakibatkan kematian pada benih ikan kakap putih.

Tabel 1. Perhitungan TBU dan TBV

\begin{tabular}{ccccc}
\hline NO & Tanggal Sampling & Satuan Unit & TBU & TBV \\
\hline 1 & $3 \mathrm{Mei}$ & & $9 \times 10^{4}$ & $5,2 \times 10^{3}$ \\
2 & $17 \mathrm{Mei}$ & $\mathrm{CFU} / \mathrm{ml}$ & $4,15 \times 10^{4}$ & $1,3 \times 10^{3}$ \\
3 & $31 \mathrm{Mei}$ & & $4,36 \times 10^{4}$ & $2,8 \times 10^{3}$ \\
4 & $14 \mathrm{Juni}$ & $4,12 \times 10^{4}$ & $2,1 \times 10^{3}$ \\
\hline
\end{tabular}

Perhitungan kandungan jumlah TBU dan TBV didapat bahwa kandungan bakteri

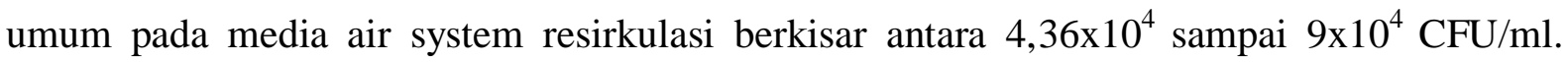
Sedangkan jumlah bakteri vibrio berkisar antara $1,3 \times 10^{3}$ sampai $5,2 \times 10^{3} \mathrm{CFU} / \mathrm{ml}$.

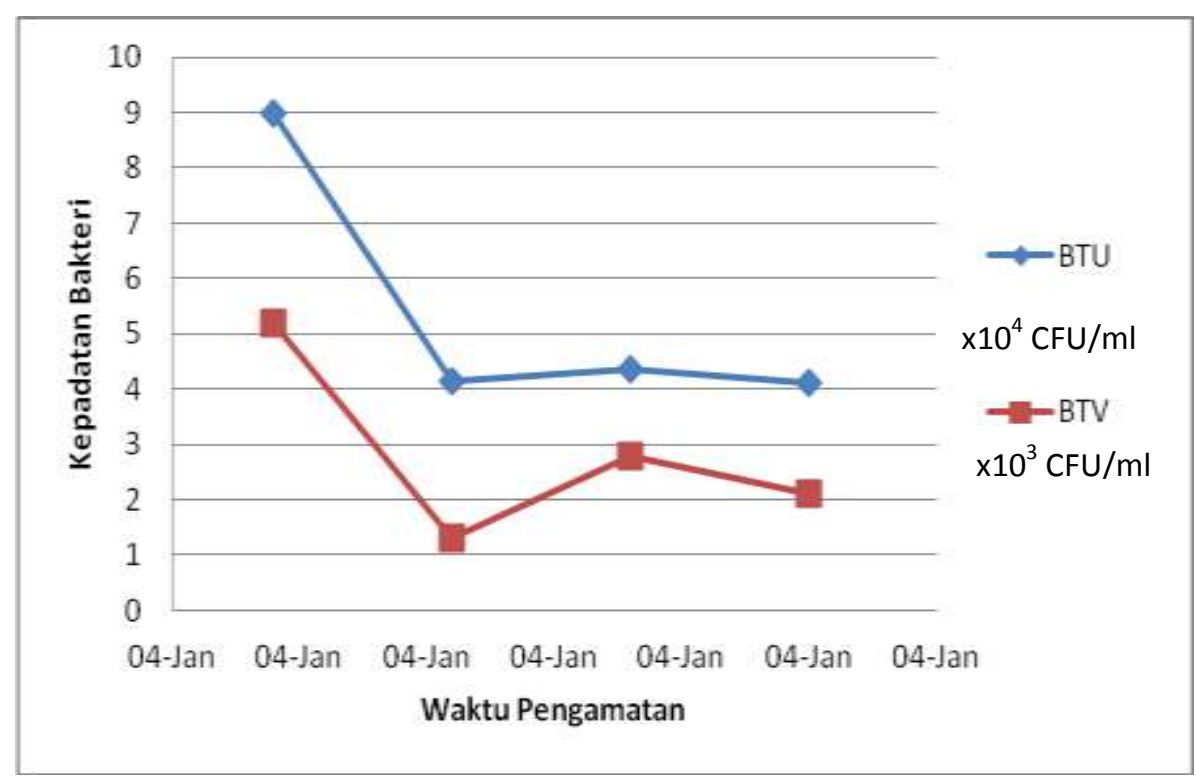

Gambar 1. Kepadatan bakteri umum dan bakteri vibrio pada media air sistem sirkulasi

Pada pengecekan jumlah bakteri umum didapat angka yang mencolok pada pengujian pertama yaitu $9 \times 10^{4} \mathrm{CFU} / \mathrm{ml}$ hal ini terjadi juga pada total bakteri vibrio, yaitu $5,2 \times 10^{3}$ $\mathrm{CFU} / \mathrm{ml}$, namun jumlah bakteri diatas tidak mengakibatkan kematian pada benih ikan kakap putih yang dipelihara. Pada pengujian selanjutnya baik total bakteri umum maupun total 
bakteri vibrio mengalami penurunan yang signifikan. Penurunan kandungan bakteri dalam media air terjadi secara fluktuatif hingga masa akhir pemeliharaan.

\section{Pengujian Kualitas Air}

Pada pengecekan kualitas air harian pada pemeliharaan benih kakap putih dengan sistem resirkulasi dapat dilihat bahwa kualitas air media pemeliharaan tidak terlalu mengalami fluktuasi dikarenakan sistem resirkulasi.

Tabel 2. Pengukuran parameter kualitas air selama masa pemeliharaan

\begin{tabular}{|c|c|c|c|c|c|c|c|c|c|c|}
\hline \multirow{2}{*}{ No } & \multirow{2}{*}{$\begin{array}{c}\text { Parameter } \\
\text { Kualitas Air }\end{array}$} & \multirow{2}{*}{$\begin{array}{l}\text { Baku } \\
\text { Mutu }\end{array}$} & \multirow{2}{*}{ Satuan } & \multicolumn{7}{|c|}{ sampling } \\
\hline & & & & I & II & III & IV & V & VI & VII \\
\hline 1. & Salinitas & $30-34$ & $\%$ & 30 & 31 & 31 & 30 & 30 & 31 & 31 \\
\hline 2. & Oksigen terlarut & $4-8$ & $\mathrm{mg} / \mathrm{L}$ & 6,91 & 5,12 & 5,22 & 6,21 & 5,12 & 6,01 & 6,15 \\
\hline 3. & Temperatur & $28-32$ & ${ }^{0} \mathrm{c}$ & 30,5 & 30,8 & 30,9 & 30,8 & 29,5 & 29,2 & 30 \\
\hline 4 & $\mathrm{pH}$ & $7-8.5$ & & 7,4 & 7,3 & 7,5 & 7,4 & 7,3 & 7,5 & 7,5 \\
\hline
\end{tabular}

Pada operasi pengujian kualitas air dilakukan tujuh kali pengecekan air. Hasil yang didapat untuk pengecekan salinitas didapatkan rentang pengukuran antara 30 - 31 ppt, keadaan ini dianggap normal karena standar baku untuk salinitas air laut berkisar 30 - 34 ppt. Menurut Boyd (1982) salinitas untuk air laut berkisar 30 - 40 ppt. Untuk pengukuran oksigen terlarut didapatkan rentang pengukuran antara 5, 12 - 6,91 mg/l, keadaan ini dalam kisaran normal karena minimal untuk hidup, biota laut membutuhkan oksigen terlarut diatas 5,00 $\mathrm{mg} / \mathrm{l}$. Untuk pengukuran suhu air didapat rentang suhu antara $29,2-30,9^{0} \mathrm{C}$, keadaan ini masih didalam baku mutu untuk pengukuran suhu yaitu rentang $28-32^{0} \mathrm{C}$, sedangkan untuk pengukuran derajat keasaman air didapat rentang antara 7,3 - 7,5, derajat keasaman yang diperbolehkan untuk pemeliharaan ikan berkisar antara $7-8,5$ hal ini bagus untuk pemeliharaan ikan kakap putih pada penelitian ini. Dari semua aspek pengukuran kualitas air diatas, masih memenuhi standar untuk kehidupan ikan yang normal sehingga tidak mengganggu hasil pemeliharaan. Menurut Bond (2011) parameter kualitas air masih diangap optimal bagi pertumbuhan larva ikan Kakap Putih pada kisaran suhu 29-30 0C; salinitas 3032 ppt; pH 6,5 - 7,4; dan DO 4,5 - 5,1 mg/l.

\section{Pertumbuhan dan angka kelulusan hidup}

Pada pemeliharaan benih kakap putih dengan menggunakan system resirkulasi didapatkan data yang cukup bagus dalam hal pertumbuhan baik panjang maupun berat ikan 
kakap putih. Ikan kakap putih pada awal penebaran memiliki panjang rata-rata $3,5 \mathrm{~cm}$ dan berat rata-rata 1,01 gr. Setelah dua bulan pemeliharaan panjang rata-rata ikan kakap putih mencapai 9,9 cm dan berat rata-rata 9,76 gr. Untuk angka kelulusan hidup didapat angka SR 93,5\%, dari jumlah awal tebar 3000 ekor dan akhir masa pemeliharaan 2805 ekor.

Tabel. 3. Pertumbuhan benih ikan kakap putih pada media air sistem sirkulasi

\begin{tabular}{cccc}
\hline No & Tanggal Sampling & Panjang rata-rata $(\mathrm{cm})$ & Berat rata-rata $(\mathrm{gr})$ \\
\hline 1 & $28 \mathrm{April}$ & 3,5 & 1,01 \\
2 & $05 \mathrm{Mei}$ & 4,3 & 1,82 \\
3 & $12 \mathrm{Mei}$ & 5,5 & 3,20 \\
4 & $19 \mathrm{Mei}$ & 6,4 & 4,34 \\
5 & $26 \mathrm{Mei}$ & 7,6 & 5,52 \\
6 & $02 \mathrm{Juni}$ & 8,0 & 6,04 \\
7 & 09 Juni & 8,6 & 7,67 \\
8 & $16 \mathrm{Juni}$ & 9,2 & 8,44 \\
9 & $23 \mathrm{Juni}$ & 9,9 & 9,76 \\
\hline
\end{tabular}

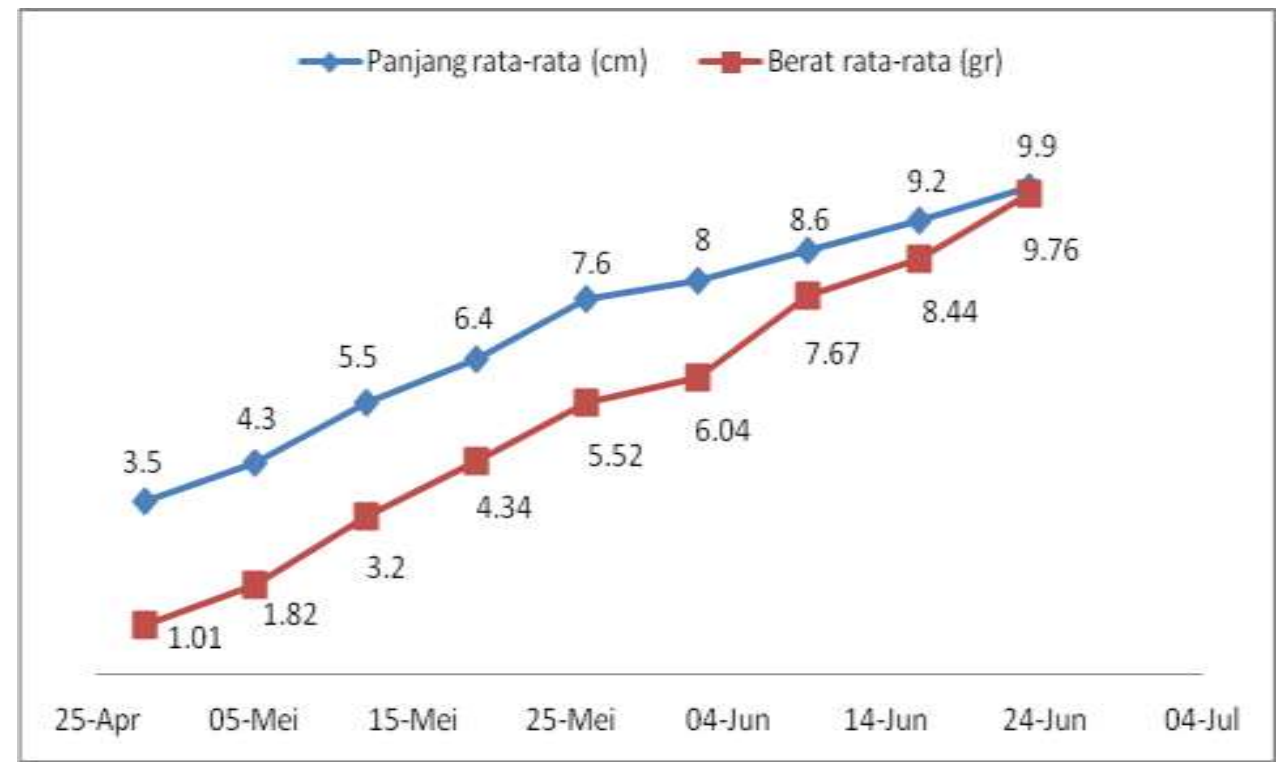

Gambar 2. Laju pertumbuhan panjang dan berat benih ikan Kakap Putih pada media air sistem sirkulasi

\section{KESIMPULAN}

Pemeliharaan benih kakap putih dengan system resirkulasi sangat bagus untuk mendukung keberhasilan pembenihan. Pada perhitungan TBU dan TBV dengan sistem resirkulasi belum memperlihatkan perbedaan yang nyata dibandingkan dengan sistem yang bukan resirkulasi, ini dimungkinkan masih belum optimalnya sistem filterisasi bakteri pada media pemeliharaan. Kualitas air pada system resirkulasi lebih stabil dan tidak terlalu 
terpengaruh dengan cuaca dan iklim. Pada pertumbuhan dan angka kelulusan hidup benih cukup bagus dan dapat menekan jumlah kematian ikan kakap putih pada penelitian ini.

\section{REFERENSI}

Bond. M. M., 2011. Teknik Kombinasi Menggunakan Imunostimulan dan Obat pada Pakan Buatan untuk Memberantas Bakteri pada Ikan Kakap Putih (Lates calcarifer, Bloch). Jurnal Perikanan dan Kelautan. Vol.I. (1): 39-42

Boyd, C.E., 1982. Water Quality Management for Pond Fish Culture. Elsevier Scientif Publishing Company, New York, USA.

Novriadi, R., Hermawan, T., Ibtisam., Dikrurrahman,. Kadari, M., Herault, M., Fournier, V., Seguin, P. 2014. Respons imun dan pertumbuhan ikan kakap putih yang diberi pakan protein hidrolisis. Jurnal Akuakultur Indonesia. 13 (2), 179-188

Mayunar. 1991. Pemijahan Dan Pemeliharaan Larva Ikan Kakap Putih (Lates calcarifer). Oseana, Volume XVI, (4): 21 - 29

Sutiknowati, L.I. 2011. Kajian mikrobio-logis terhadap kualitas perairan Laut Belitung Barat, Provinsi Bangka Belitung. Oseanologi dan Limnologi di Indonesia, 37(3): 521-545. 